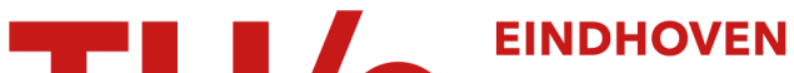 \\ UNIVERSITY OF \\ TECHNOLOGY
}

\section{Drying deformable media, kinetics, shrinkage and stresses}

Citation for published version (APA):

Ketelaars, A. A. J. (1994). Drying deformable media, kinetics, shrinkage and stresses. Drying Technology, 12(7), 983-987. https://doi.org/10.1080/07373939408960008

DOI:

10.1080/07373939408960008

Document status and date:

Published: 01/01/1994

\section{Document Version:}

Publisher's PDF, also known as Version of Record (includes final page, issue and volume numbers)

\section{Please check the document version of this publication:}

- A submitted manuscript is the version of the article upon submission and before peer-review. There can be important differences between the submitted version and the official published version of record. People interested in the research are advised to contact the author for the final version of the publication, or visit the $\mathrm{DOI}$ to the publisher's website.

- The final author version and the galley proof are versions of the publication after peer review.

- The final published version features the final layout of the paper including the volume, issue and page numbers.

Link to publication

\section{General rights}

Copyright and moral rights for the publications made accessible in the public portal are retained by the authors and/or other copyright owners and it is a condition of accessing publications that users recognise and abide by the legal requirements associated with these rights.

- Users may download and print one copy of any publication from the public portal for the purpose of private study or research.

- You may not further distribute the material or use it for any profit-making activity or commercial gain

- You may freely distribute the URL identifying the publication in the public portal.

If the publication is distributed under the terms of Article 25fa of the Dutch Copyright Act, indicated by the "Taverne" license above, please follow below link for the End User Agreement:

www.tue.nl/taverne

Take down policy

If you believe that this document breaches copyright please contact us at:

openaccess@tue.nl

providing details and we will investigate your claim. 
THESIS SUMMARY

\title{
DRYING DEFORMABLE MEDIA \\ KINETICS, SHRINKAGE AND STRESSES
}

\begin{abstract}
A.A.J. Ketelaars
Eindhoven University of Technology, Department of Chemical Engineering, Laboratory of Separation Processes, P.O. Box 513, 5600 MB the Netherlands
\end{abstract}

Ph.D.-thesis, promotors P.J.A.M. Kerkhof, M. Roques and W.J. Coumans

Key Words and Phrases: diffusion coefficient, moisture concentration profiles, drying curves, shrinkage, simulations, stresses

\section{EXTENDED SUMMARY Ph.D. THESIS}

Shrinkage occurs during drying of many materials. Moisture concentration gradients in the material and corresponding gradients in the degree of shrinkage will lead to drying stresses. Controlling these stresses is important since they can lead to deformation and cracking of the product. Since drying stresses originate primarily from moisture concentration gradients, a reliable prediction of the evolution of these gradients in the course of drying is essential. This description is complicated by the fact that shrinkage and stresses influence these gradients. In many papers on drying stresses, drying kinetics has not received sufficient attention and drying stresses are calculated based on unreliable moisture concentration profiles. A successful description of the occurrence of drying stresses, and thus the control of product quality, must start with a proper description of the kinetics of drying. The scope of this thesis was to develop and verify a model for drying of clays, with special attention for shrinkage and stresses. 
In chapter two of the thesis a drying kinetics model is developed based on the diffusion equation. Deformations due to shrinkage and stresses are taken into account. Essential when using a diffusion equation is a reliable experimental determination of the diffusion coefficient as a function of moisture content. Therefore chapter 3 is concerned with an experimental method for the derivation of the so called actual diffusion coefficient, based on accurate measurements of transient moisture concentration profiles. Results for three clays are included. In chapter 4 results of the traditional method for the determination of the so called apparent diffusion coefficient, derived from drying curves, are compared with actual diffusion coefficients. The influence of shrinkage on drying behaviour is discussed in chapter 5. Multi-dimensional simulations are performed in order to get a quantitative idea of the importance of shrinkage in drying of clays. Chapter 6 is concerned with drying stresses. Finally, some suggestions for future research are given in chapter 7 .

The mathematical formulation of mass transfer is based on the diffusion equation. In this equation the flux of moisture is proportional to the moisture concentration gradient. The diffusion equation can be derived from a mechanistic description of mass transfer in porous media. With some minor simplifications it can be reasoned from this mechanistic description that the diffusion coefficient is, under isothermal conditions, a function of moisture content only. This moisture concentration dependency has to be determined experimentally. For deforming media, the deformation of the solid phase (shrinkage) has to be accounted for. It is shown that a generalized mathematical formulation of the diffusion equation can be used for both deforming and rigid systems.

Generally, the experimental determination of the-diffusion coefficient as a function of moisture content is difficult. Very often drying curves are used, however, a functional relation between diffusion coefficient and moisture content has to be assumed. This functional relation is unknown, as a matter a fact, finding such a relation was the purpose of the experiment in the first place. In this study the diffusion coefficient determined from drying curves is called the apparent diffusion coefficient. A different approach introduced here is to derive the diffusion coefficient from the evolution of the moisture concentra- 
tion profiles in the material. This coefficient is called the actual diffusion coefficient. An experimental method for determining transient moisture concentration profiles should be non destructive and should give a high spatial resolution. For this purpose scanning neutron radiography is used. The accuracy of these profiles is high enough to permit the direct determination of the diffusion coefficient as a function of moisture content. An example of the evolution of moisture concentration profiles with time for a kaolin clay is given in Figure 1.

From moisture concentration profiles the actual diffusion coefficient can be determined by means of direct integration. From various experiments the actual diffusion coefficient for this clay (Figure 2) could be derived.

An extensive comparison of actual and apparent diffusion coefficients has been made. An analysis of apparent diffusion coefficients shows that no unambiguous results can be obtained; i.e. the diffusion coefficient depends on experimental conditions: It is shown that apparent diffusion coefficients are only valid over a limited range in moisture content. This explains why, for the same material, different diffusion coefficients were found for different experimental conditions.

With the unambiguous actual diffusion coefficient drying curves for various experimental conditions can be described very well. Although it was not possible to derive consistent diffusion coefficient data from drying curves, this does not imply that a diffusion equation is inadequate to describe the drying process. For clays drying curves are simply not the correct experiments to derive drying kinetics data.

Shrinkage has to be accounted for in the diffusion equation. Simulations have been performed for three types of shrinkage: isotropic, unidirectional and noshrinkage. Since many materials show isotropic shrinkage behaviour, unidirectional and no-shrinkage should be considered as approximations of the actual material behaviour. A characteristic feature of isotropic shrinkage is the decrease of external surface area. As a result of this the constant rate period is absent. In case of isotropic shrinkage there are two compensating effects with respect to drying rates: the decrease of surface area in the beginning of drying 


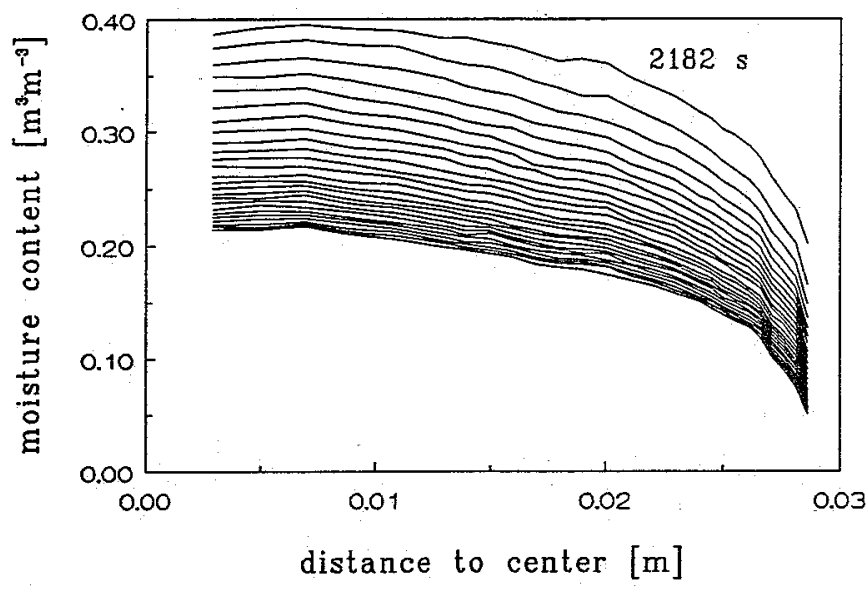

FIGURE 1. Moisture concentration profile as a function of time for a clay. Sample height $=2.95 \mathrm{~cm}, T=21^{\circ} \mathrm{C}$. Time interval between subsequent profiles is $1460 \mathrm{~s}$, first profile at $2182 \mathrm{~s}$, total drying time is 11 hrs.

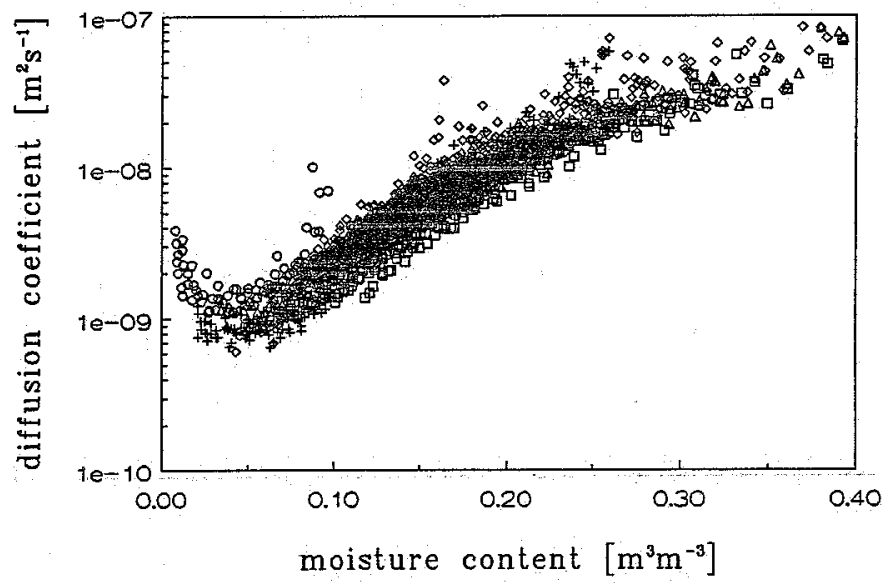

FIGURE 2. Actual diffusion coefficient as a function of moisture content for a kaolin clay. Figure contains approximately two thousand points. 
is compensated by a decrease of the diffusion path-length in the material towards the end of the drying process. As a consequence the overall effect of shrinkage on drying curves is limited.

Drying stresses have been calculated for a simple two-dimensional situation (linear elastic, plane stress). Due to low values of the Young's modulus and flat moisture concentration profiles, hardly any stress arises in the beginning of drying. Significant stresses develop only after a few hours when moisture content of the material has decreased and moisture concentration gradients are present. It is shown that, for the situation considered here, deformations due to shrinkage are very large compared to the deformations due to stresses. Therefore, from a drying kinetics point of view, deformations due to stresses can be neglected.

\section{ACKNOWIEDGEMENTS}

The work described in this thesis has been performed in corporation with the structural ceramics department of TNO-TPD. The financial support of the Nederlandse Maatschappij voor Energie en Milieu B.V. (NOVEM), the Koninklijk Verbond van Nederlandse Baksteenfabrikanten (KNB) and the Nederlandse Dakpannen Corporatie ( $\mathrm{NeDaCo}$ ) is acknowledged. 